\title{
Detection of SARS-CoV-2-RNA in post-mortem samples of human eyes
}

\author{
Josef Penkava ${ }^{1} \cdot$ Maximilian Muenchhoff ${ }^{2,3} \cdot$ Irina Badell $^{2} \cdot$ Andreas Osterman $^{2} \cdot$ Claire Delbridge $^{4}$. \\ Florian Niederbuchner ${ }^{5} \cdot$ Sarah Soliman $^{6} \cdot$ Martina Rudelius $^{6} \cdot$ Alexander Graf $^{7} \cdot$ Stefan Krebs $^{7} \cdot$ Helmut Blum $^{7}$. \\ Michael Ulbig ${ }^{1}$. Carmen Baumann ${ }^{1}$ - Daniel Zapp ${ }^{1}$ - Mathias Maier ${ }^{1}$. Oliver T. Keppler ${ }^{2,3}$. Chris P. Lohmann ${ }^{1}$. \\ Stephan Ledderose ${ }^{6}$
}

Received: 22 September 2021 / Revised: 16 November 2021 / Accepted: 16 December 2021 / Published online: 28 December 2021 (c) The Author(s) 2021

\begin{abstract}
Purpose To detect SARS-CoV-2 RNA in post-mortem human eyes. Ocular symptoms are common in patients with COVID19. In some cases, they can occur before the onset of respiratory and other symptoms. Accordingly, SARS-CoV-2 RNA has been detected in conjunctival samples and tear film of patients suffering from COVID-19. However, the detection and clinical relevance of intravitreal SARS-CoV-2 RNA still remain unclear due to so far contradictory reports in the literature. Methods In our study 20 patients with confirmed diagnosis of COVID-19 were evaluated post-mortem to assess the conjunctival and intraocular presence of SARS-CoV-2 RNA using sterile pulmonary and conjunctival swabs as well as intravitreal biopsies (IVB) via needle puncture. SARS-CoV-2 PCR and whole genome sequencing from the samples of the deceased patients were performed. Medical history and comorbidities of all subjects were recorded and analyzed for correlations with viral data.

Results SARS-CoV-2 RNA was detected in 10 conjunctival (50\%) and 6 vitreal (30\%) samples. SARS-CoV-2 whole genome sequencing showed the distribution of cases largely reflecting the frequency of circulating lineages in the Munich area at the time of examination with no preponderance of specific variants. Especially there was no association between the presence of SARS-CoV-2 RNA in IVBs and infection with the variant of concern (VOC) alpha. Viral load in bronchial samples correlated positively with load in conjunctiva but not the vitreous.

Conclusion SARS-CoV-2 RNA can be detected post mortem in conjunctival tissues and IVBs. This is relevant to the planning of ophthalmologic surgical procedures in COVID-19 patients, such as pars plana vitrectomy or corneal transplantation. Furthermore, not only during surgery but also in an outpatient setting it is important to emphasize the need for personal protection in order to avoid infection and spreading of SARS-CoV-2. Prospective studies are needed, especially to determine the clinical relevance of conjunctival and intravitreal SARS-CoV-2 detection concerning intraocular affection in active COVID-19 state and in post-COVID syndrome.
\end{abstract}

Keywords COVID-19 $\cdot$ SARS-CoV-2 $\cdot$ Conjunctivitis $\cdot$ Vitreous sample $\cdot$ Intraocular involvement

Chris P. Lohmann deceased

Josef Penkava

Josef.penkava@mri.tum.de

1 Department of Ophthalmology, Technical University Munich, Munich, Germany

2 Max von Pettenkofer Institute \& Gene Center, Virology, National Reference Center for Retroviruses, LMU München, Munich, Germany

3 German Center for Infection Research, Partner Site Munich, Munich, Germany
4 Department of Pathology and Neuropathology, TUM School of Medicine, Technical University Munich, Munich, Germany

5 Department of Internal Medicine, Kliniken Südostbayern, Trostberg, Germany

6 Department of Pathology, Ludwig-Maximilian University Munich, Munich, Germany

7 Laboratory for Functional Genome Analysis, Gene Center, Ludwig-Maximilians-University, Munich, Germany 


\section{Key messages}

- In the present study, SARS-CoV-2 RNA was detected in $10(50 \%)$ conjunctival swabs and $6(30 \%)$ vitreous samples

- Viral load in bronchial samples was positively correlated with viral load in conjunctiva

- Our results suggest, that the "variant of concern" (VOC)-alpha virus does not have increased tropism for intraocular tissue

- Prospective studies are needed to determine the clinical relevance of conjunctival and intravitreal SARS-CoV-2-RNA in active COVID-19 state and in post-COVID syndrome

\section{Introduction}

Since late December 2019, COVID-19 caused by the SARS-CoV-2 virus has become a global pandemic affecting humanity in an unprecedented way [1]. Since then, knowledge about the disease has rapidly expanded thanks to intensive research. It became apparent that COVID-19 is not only a pulmonary disease but can affect almost all other organ systems [2].

Ocular involvement has been reported in several studies. Eye symptoms occur in approximately one third of patients with SARS-CoV-2 infection, particularly in those with more severe disease [3, 4]. The most frequent ocular manifestation of SARS-CoV-2 infection is conjunctivitis, which may occur as a possible initial manifestation of COVID-19 [5-9]. In addition, retinal changes such as cotton-wool spots and retinal microhemorrhages have also been described $[5,10,11]$. Whether these symptoms result from direct infection of the eye, immunologic reactions, or ischemic damage to the visual system is not clear [5].

SARS-CoV-2 is mainly transmitted via aerosols and binds to the angiotensin-converting enzyme-2 (ACE-2) receptor to invade the host cell [12]. Involvement of the ocular surface may reflect high expression of the ACE-2 receptor in the conjunctiva and cornea $[13,14]$. The ACE- 2 receptor has also been detected in the aqueous humor and retina $[15,16]$. Thus, direct infection of the eye by SARS-CoV-2 is theoretically conceivable.

Data on intraocular SARS-CoV-2, however, are still sparse with contradictory results in the available small post-mortem studies. For example, in one case report, SARS-CoV-2 RNA was detected in conjunctival swabs, whereas anterior chamber and vitreous samples were negative [17]. Another study showed a low prevalence of SARS-CoV-2 RNA in conjunctival and vitreous samples from COVID-19-positive decedents [18]. Casagrande et al. detected viral RNA of SARS-CoV-2 in the human retina of COVID-19 patients post mortem [19]. In contrast, no conjunctival, corneal, or intraocular SARS-CoV-2 RNA was found in other post-mortem studies [20-23].

SARS-CoV-2 involvement of the ocular surface is highly relevant particularly when planning and performing ophthalmic surgery, as infectious aerosols can be generated during ophthalmic procedures in SARS-CoV-2 positive patients [24]. The detection of viral RNA in the intraocular milieu may also provide a clue to the pathogenesis of ophthalmologic symptoms during COVID-19-related intraocular disease [25]. We therefore investigated in our post-mortem study whether SARS-CoV-2 RNA can be detected in the conjunctiva and vitreous body.

\section{Materials and methods}

\section{Post-mortem sample collection}

Between December 2020 and May 2021, we performed post-mortem examinations in individuals with confirmed SARS-CoV-2 infection who had died at the LudwigMaximilian University Hospital in Munich. Until autopsy, bodies were stored at $+4{ }^{\circ} \mathrm{C}$ for up to $78 \mathrm{~h}$. The eyelids of the deceased were closed immediately after death in order to reduce postmortal evaporation of conjunctival fluid. Conjunctival swabs were taken from the right eye before autopsy. To obtain an adequate amount of conjunctival fluid, the deep fornix was wiped out. Thereafter, approximately $2 \mathrm{ml}$ of vitreous was collected by intravitreal biopsy (IVB) directly through the anterior part of the bulbar conjunctiva from the right eye under sterile conditions with a 27-gauge needle (B. Braun Melsungen AG, Melsungen, Germany). The posterior chamber was then restored with balanced salt solution (B. Braun Melsungen AG, Melsungen, Germany). During autopsy, a swab was obtained from the bronchial system. For all specimen collection, nylon flocked swabs with liquid Amies transport medium were used (eSwabs, Copan diagnostics, Brescia, Italy). Conjunctival swabs, IVBs, and bronchial 
swabs were sent immediately at room temperature to the Department of Virology and tested immediately for SARSCoV-2 RNA by qRT-PCR. Only subjects with evidence of SARS-CoV-2 RNA in the bronchial swab were included in the study. Clinical reports were reviewed for pre-existing medical conditions. None of the deceased patients had a history of ocular disease or ocular surgery. Cause of death was determined at autopsy, which was performed according to published best practice [26]. This study was approved by the local Institutional Review Board (No. 20-245), and written informed consent was obtained from the next of kin.

\section{Detection and quantification of SARS-CoV-2 RNA}

Fresh paired post-mortem conjunctival, bronchial, and vitreous samples from 20 different donors were analyzed using the fully automated Roche cobas ${ }^{\circledR}$ 6800/8800 system (Roche Diagnostics, Penzberg, Germany). For quantification, standard curves were generated in multiple replicates using a commercially available standard for calibration (Instand e.V., Düsseldorf, Germany). Viral loads of samples were calculated as SARS-CoV-2 ORF1ab copy numbers per $1 \mathrm{ml}$ of swab medium or vitreous fluid, respectively. Positive and negative control samples were included in each run. These measurements were performed at the fully accredited diagnostic laboratory of the Department of Virology at the Pettenkofer Institute.

\section{Genome sequencing}

Total RNA was extracted from bronchial samples using the DSP virus/pathogen Mini Kit on a Qiasymphony robot (Qiagen, Hilden, Germany). Amplicon pools spanning the whole virus genome were prepared using the ARTIC protocol multiplex PCR, subsequently converted to barcoded sequencing libraries with the Nextera XT kit (Illumina, San Diego, USA) and sequenced on an Illumina Hiseq1500 sequencer (Illumina, San Diego, USA) as described previously [27]. The sequenced amplicons were demultiplexed and consensus sequences were generated using the iVar pipeline. The pileup files served as input for the consensus sequence generation within iVar where only variants that had a minimum read depth of 20 and a minimum frequency of 0.9 were considered. Phylogenetic analyses were achieved with the web and analysis platform Auspice using the SARS-Cov-2 build (https://github.com/nextstrain/ncov) and the bioinformatic toolkit augur. The consensus sequences and meta data for the samples were uploaded to the GISAID repository. GISAID accession numbers for the cases of this study are shown in Table 2.

\section{Statistical analysis}

Statistical analyses were performed using Microsoft Excel version Microsoft Office 365 (Microsoft, Redmond, USA) and GraphPad Prism version 9 software (GraphPad Software, San Diego, USA). Bivariate correlation analyses between viral load in bronchial samples and viral load in conjunctiva and vitreous respectively were performed using the Spearman rank correlation test. The Spearman rank correlation is a non-parametric test and the Spearman rank correlation coefficient, i.e., Spearman's Rho (r) measures the strength and direction of association between two ranked variables. $P$ values $\leq 0.05$ were considered statistically significant.

\section{Results}

IVBs and conjunctival swabs were obtained during autopsy from 20 individuals with confirmed SARS-CoV-2 RNA in bronchial swabs. Patient characteristics are summarized in Table 1.

The median age at death of the study participants was 63 (44-95) years. Six (30\%) of the deceased patients were female. In terms of comorbidities, $16(80 \%)$ had known coronary artery disease, $16(80 \%)$ had hypertension, $10(50 \%)$ had chronic renal failure, nine (45\%) had dyslipidemia, five (25\%) had type II diabetes mellitus, four (20\%) had dementia, three (15\%) had COPD, two (10\%) had Parkinson's disease, and two (10\%) had a post-organ-transplant condition. Ten patients $(50 \%)$ were treated in the intensive care unit (ICU) at the time of death. The median time of positivity for SARS-CoV-2 RNA in nasopharyngeal swabs was 10 days (2-94) and the median time from exitus to autopsy was 44 (19-78) h. Causes of death were respiratory failure in eight patients (40\%), sepsis in four (20\%), multiorgan failure in three $(15 \%)$, cardiorespiratory failure in two (10\%), pulmonary embolism in two (10\%), and intracranial hemorrhage in one (5\%) of the patients. Neither specific ocular symptoms related to COVID-19 nor previously known ocular comorbidities or surgical procedures were listed in all the medical records.

SARS-CoV-2 RNA was detected in $10(50 \%)$ conjunctival swabs and 6 (30\%) IVBs (Fig. 1a). A higher proportion of patients with a positive conjunctival test for SARS-CoV-2 RNA also had a positive IVB result. Thus, among the 10 patients with positive conjunctival swab, SARS-CoV-2 RNA was detected in the vitreous of 5 patients, but only one patient with a negative conjunctival swab had a positive IVB.

Viral load in bronchial samples was positively correlated with viral load in conjunctiva (Spearman rank correlation test; $r=0.49, p=0.027$; Fig. $1 b$ ) but not the 
Table 1 Demographics and clinical characteristics

\begin{tabular}{|c|c|c|c|c|c|c|}
\hline Pat. ID & Sex & Age & $\begin{array}{l}\text { Positive for (in } \\
\text { days) }\end{array}$ & ICU & $\begin{array}{l}\text { Time until autopsy } \\
\text { (in hours) }\end{array}$ & Cause of death \\
\hline 1 & $\mathrm{~F}$ & 53 & 18 & $\mathrm{y}$ & 39 & Intracranial bleeding \\
\hline 2 & M & 95 & 2 & $\mathrm{n}$ & 27 & Sepsis \\
\hline 3 & M & 66 & 2 & $\mathrm{y}$ & 52 & Cardiorespiratory failure \\
\hline 4 & M & 72 & 8 & $\mathrm{n}$ & 46 & Respiratory failure \\
\hline 5 & $\mathrm{~F}$ & 86 & 6 & $\mathrm{n}$ & 42 & Pulmonary embolism \\
\hline 6 & M & 95 & 6 & $\mathrm{n}$ & 69 & Respiratory failure \\
\hline 7 & $\mathrm{~F}$ & 83 & 10 & $\mathrm{n}$ & 19 & Respiratory failure \\
\hline 8 & $\mathrm{~F}$ & 80 & 12 & $\mathrm{n}$ & 68 & Respiratory failure \\
\hline 9 & $\mathrm{~F}$ & 77 & 5 & $\mathrm{n}$ & 28 & Cardiorespiratory failure \\
\hline 10 & M & 84 & 4 & $\mathrm{n}$ & 41 & Respiratory failure \\
\hline 11 & M & 81 & 26 & $\mathrm{y}$ & 38 & Respiratory failure \\
\hline 12 & $\mathrm{M}$ & 72 & 9 & $\mathrm{y}$ & 70 & Respiratory failure \\
\hline 13 & M & 73 & 34 & $\mathrm{y}$ & 68 & Multiorgan failure \\
\hline 14 & M & 59 & 94 & $\mathrm{y}$ & 31 & Multiorgan failure \\
\hline 15 & $\mathrm{~F}$ & 81 & 2 & $\mathrm{n}$ & 33 & Sepsis \\
\hline 16 & $\mathrm{M}$ & 59 & 19 & $\mathrm{y}$ & 26 & Multiorgan failure \\
\hline 17 & M & 52 & 28 & $\mathrm{y}$ & 46 & sepsis \\
\hline 18 & M & 62 & 19 & $\mathrm{y}$ & 36 & Respiratory failure \\
\hline 19 & M & 60 & 12 & $\mathrm{n}$ & 78 & Pulmonary embolism \\
\hline 20 & M & 45 & 11 & $\mathrm{y}$ & 23 & Sepsis \\
\hline
\end{tabular}

vitreous ( $r=0.45, p=0.058$, Fig. $1 \mathrm{c})$. Patients in the ICU were positive for SARS-CoV-2-RNA for more days on average than patients in the normal ward (Mean 26 days vs. 6.7 days) and a larger fraction of ICU patients tested positive for SARS-CoV-2-RNA in conjunctival swabs or IVBs ( $80 \%$ vs $30 \%)$.

To analyze if the presence of SARS-CoV-2 RNA in the eye is associated with infection by specific SARS-CoV-2 variants such as the recently emerged variant of concern (VOC), B.1.1.7/alpha, we performed SARS-CoV-2 whole genome sequencing from respiratory samples of the deceased patients. We obtained near full-length sequences (>95\% genome coverage) for 13 of these cases that were subsequently used for phylogenetic analysis. The distribution of cases largely reflected the frequency of circulating lineages in the Munich area at that time (Fig. 2). None of the four cases who were infected with VOC alpha had a SARS-CoV-2-RNA-positive IVB result, whereas four of the nine cases infected with a non-VOC strain tested positive for viral RNA in the IVB. Hence, there was no association between the presence of SARS-CoV-2 RNA in IVBs and infection with the VOC alpha. Results of SARS-CoV-2 RNA
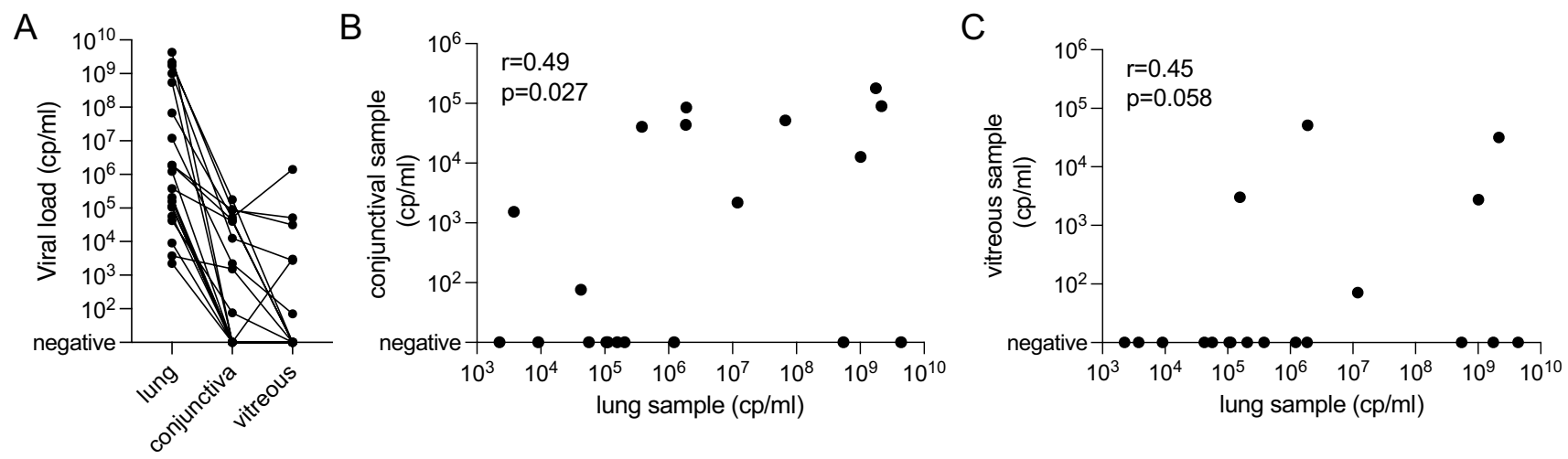

Fig. 1 Viral loads of SARS-CoV-2 in conjunctival swabs and vitreous samples. (a) Viral loads are shown as SARS-CoV-2 ORF1ab copy numbers per $\mathrm{ml}$ for bronchial, conjunctival and vitreous samples.
Results from the same patient are connected by a line. (b and c) Viral load levels of conjunctival and vitreous samples are shown in relation to bronchial samples. Spearman rank correlation tests are indicated 
Fig. 2 Phylogenetic relationship of SARS-CoV-2 post-mortem samples and samples from the Munich Metropolitean Area.

Time-resolved maximum likelihood phylogeny of 2625 SARS-CoV-2 genomes from the larger Munich area obtained between March 2020 and February 2021. Nextstrain/Pangolin/ WHO nomenclature clades are indicated above the main branches. The sequences of the cases in this study are indicated as colored dots. Cases with presence of SARS-CoV-2 RNA in the conjunctiva are marked by a black circle, and cases with detection of SARS-CoVRNA in the vitreous body are indicated by a square. GISAID accession numbers for the cases of this study are shown in Table 2
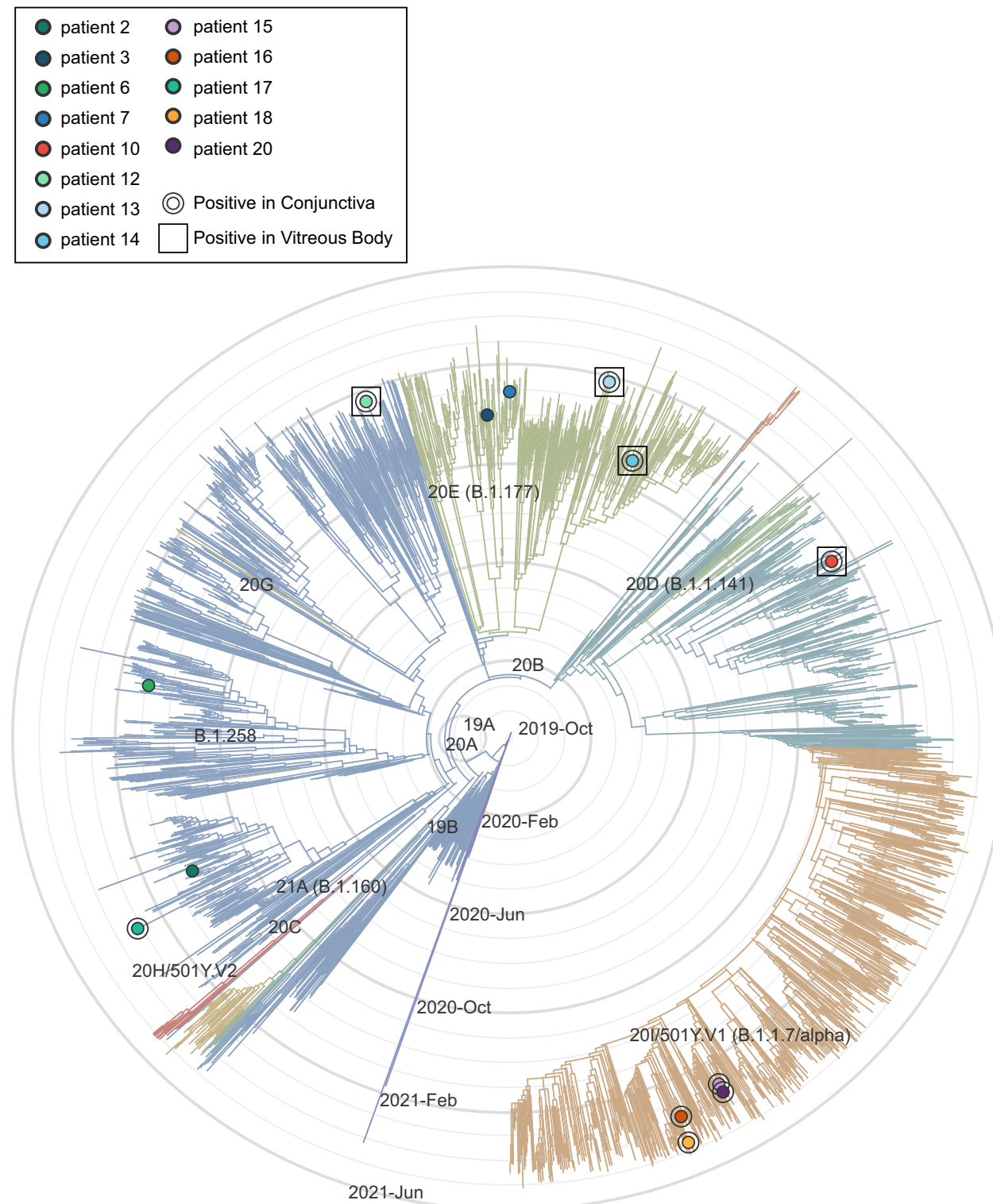

detection, quantification, and whole genome sequencing are summarized in Table 2.

\section{Discussion}

This autopsy study investigated whether SARS-CoV-2 RNA could be detected in post-mortem samples of conjunctiva and vitreous of patients who had died from COVID-19. Since COVID-19 was first described in December 2019, ocular involvement in COVID-19 patients has been reported several times, and the conjunctiva and lacrimal fluid have been considered as a possible viral reservoir [3, 28-30]. The most common ophthalmological symptoms in COVID19 are dry, watery, and painful eyes and photophobia [31]. Some studies have also described ischemic retinal changes in patients after infection with SARS-CoV-2 [32-35]. However, to date, it is still unclear how SARS-CoV-2 can target the eye and how frequently ocular involvement occurs in patients with COVID-19.

In the present study, we detected SARS-CoV-2 RNA in $50 \%$ of the examined conjunctival specimens and in $30 \%$ of the examined IVBs. Our results are in accordance with previous studies that found SARS-CoV-2 RNA within the eye $[18,19,24]$. In other studies, SARS-CoV-2 RNA was not detected in conjunctiva and vitreous $[17,20,21,23,36]$. One possible reason for the negative results in these studies may have been the small sample size. In our comparatively large post-mortem cohort of 20 deceased individuals, we found SARS-CoV-2 RNA in 10 conjunctival swabs and in 6 vitreous samples. There was a significant positive correlation between viral load in bronchial samples and viral load 


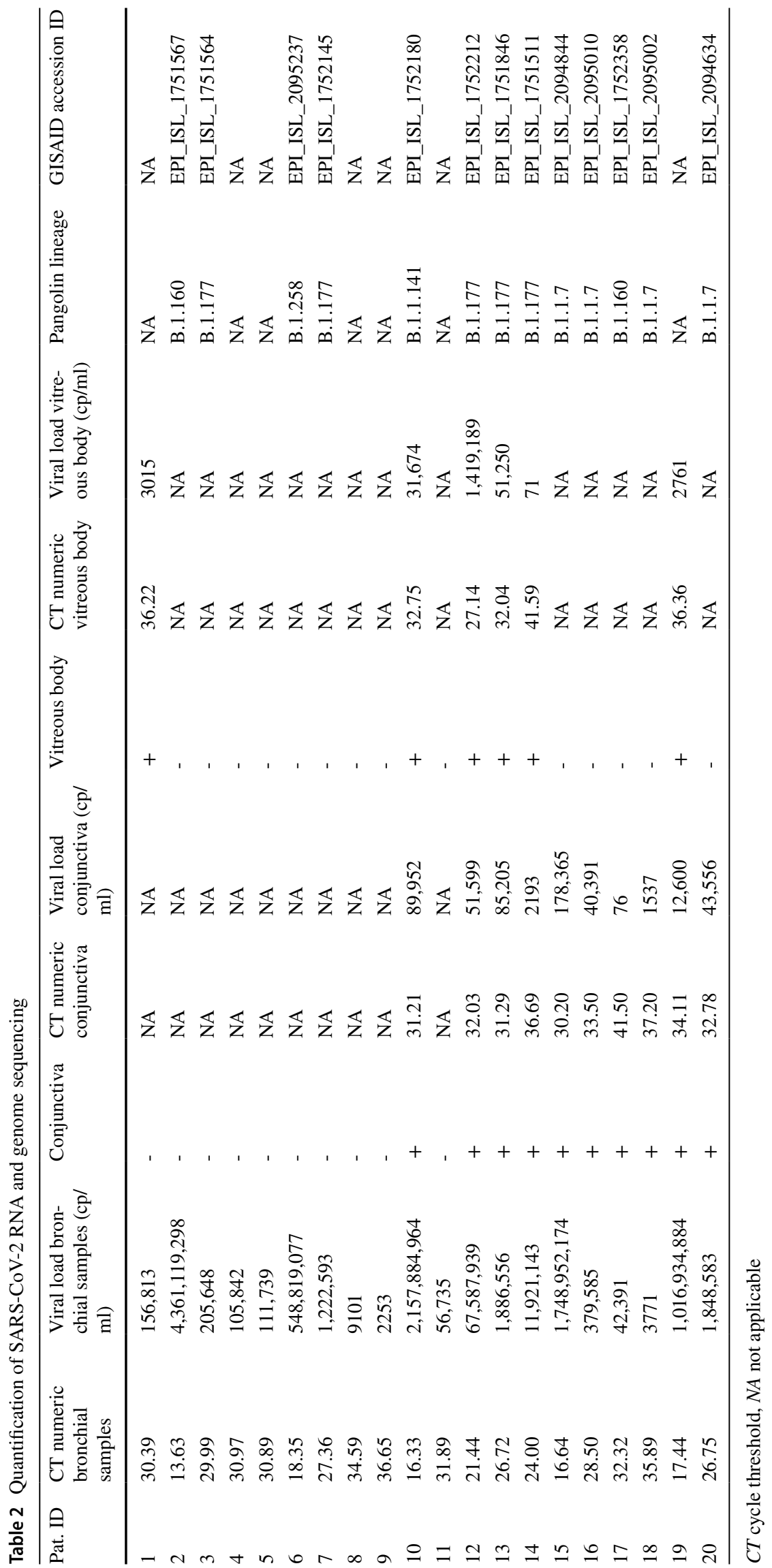


in conjunctiva, suggesting that conjunctival involvement is more likely in cases of severe COVID-19. A similar trend was observed for the association between viral load in bronchial samples and viral load in vitreous samples, which was not statistically significant, however, likely due to the overall low number of positive vitreous samples.

Conjunctival swab and IVBs were performed before autopsy and in a sterile manner. While the conjunctival swab was taken from the protected fornix, the puncture for IVB was performed directly through the anterior part of the bulbar conjunctiva. Due to post-mortem evaporation, virtually no tear fluid was present at this site at the time of puncture. These measures were intended to reduce the possibility of contamination of the vitreous samples with viral RNA by entrained tear fluid. While contamination of the vitreous by the puncture procedure cannot be ruled out completely, our results suggest that the risk is probably low. For example, in one case, the vitreous sample was positive, while the corresponding conjunctival sample was negative. In another case, a higher viral load was detected in the vitreous than in the corresponding conjunctival sample. In five subjects, the vitreous samples were negative, although viral RNA, and in some cases even high viral loads, were detected in the conjunctival samples. These results argue against accidental carryover of viral material from the conjunctiva into the interior of the eye during vitreous sample collection.

We did not find any evidence of COVID-19-related central nervous system (CNS) inflammatory disease in our cohort, which has been suggested as a possible starting point of ocular infection [23]. SARS-CoV-2 invades its host cells by binding to ACE-2 on the cell surface [37], which has been detected in ocular tissues, e.g., in conjunctiva and cornea, but also in the retina $[13,15,16]$. Given the expression of ACE-2 in the eye, it seems possible that SARS-CoV-2 may infect the conjunctiva directly from the outside and enter the interior of the eye via ACE-2. Our results support this hypothesis. It should be noted, however, that we analyzed only viral RNA and that detection of viral RNA does not necessarily imply the presence of potentially infectious viral particles. In this study, we chose PCR as a method with high sensitivity to detect even small amounts of viral RNA in the ocular region. Further studies using alternative detection methods (e.g., immunohistochemistry, electron microscopy) are needed to corroborate our results and investigate whether viral proteins and (infectious) SARS-CoV-2 particles are present in the eye during COVID-19 disease.

In our study, SARS-CoV-2 RNA could be detected intraocularly up to $78 \mathrm{~h}$ after death and up to 94 days after the first positive test. A recent report by Koo et al. showed that SARS-CoV-2 RNA was present in the aqueous humor of asymptomatically infected subjects despite negative nasal swab tests [24]. This raises the question whether and how long SARS-CoV-2 can persist in immune-privileged niches like the eye without causing any symptoms. Similarly, little information is available about the development and persistence of ocular symptoms in patients with COVID-19 and particularly post-COVID-19 syndrome. These questions need to be addressed in further prospective studies.

The possibility of altered tissue tropism of new and future SARS-CoV-2 variants, which may lead to different organ manifestations, must be considered [38]. To address this question, we performed viral sequencing and phylogenetic analyses to determine the viral lineages of our cases. The distribution corresponded to the frequency of circulating SARS-CoV-2 variants in the Munich area at that particular time. In particular, the proportion of cases in which SARSCoV-2 RNA was detected in the vitreous was not increased in patients infected with the "variant of concern" (VOC)alpha virus, suggesting that this variant does not have increased tropism for intraocular tissue.

Although the infectivity of ocular fluids during COVID19 disease still needs to be verified in cell culture-based studies, our results suggest that ophthalmologists should wear appropriate protective equipment when performing ocular procedures on COVID-19 patients, such as pars plana vitrectomy or corneal transplantation. In addition, it seems important to pay special attention to personal protection and strictly adhere to appropriate hygiene measures not only during surgical procedures but also in the outpatient setting to prevent infections and the spread of SARS-CoV-2. Therefore, preventive management concepts analogous to the management of patients with keratoconjunctivitis epidemica should be considered.

In conclusion, we found that genetic material of SARSCoV-2 is present in the conjunctiva and vitreous of individuals severely affected by COVID-19. Further studies are needed to better understand the pathology and significance of ocular involvement in COVID-19.

Acknowledgements We would like to dedicate this manuscript to our colleague Prof. Dr. med. Dr. (Lond.) Chris P. Lohmann, chair of the Department of Ophthalmology at Technical University Munich, who passed away suddenly in September 2021. We thank Thomas Kirchner, Max Knott and Tabula humulogica for intellectual counselling.

Authors' contributions JP: idea of the project, writing, and reviewing the figures and the manuscript; MM: laboratory work, figures, and reviewing the manuscript; IB: laboratory work, reviewing the figures, and reviewing the manuscript; AO: laboratory work, and reviewing the manuscript CD: reviewing the manuscript and intellectual counselling; FN: reviewing the manuscript and intellectual counselling; SS: collecting samples and reviewing the manuscript; MR: intellectual counselling and reviewing the manuscript; $\mathrm{AG}, \mathrm{SK}$, and $\mathrm{HB}$ : viral genome sequencing and reviewing the manuscript; MU, CB, DZ, MM, and CPL reviewing the figures, reviewing the manuscript, and intellectual counselling; OK: intellectual counselling and reviewing the manuscript; SL: writing and reviewing of the manuscript and the figures, collecting samples, and intellectual counselling. 
Funding Open Access funding enabled and organized by Projekt DEAL.

Data availability All datasets on which the conclusions of the paper rely are available and stated in this manuscript.

\section{Declarations}

Ethics approval This study was approved by the local Institutional Review Board (Ethikkommission Ludwig-Maximilian-Universität, Munich, No. 20-245), and written informed consent was obtained from the next of kin.

Conflict of interest The authors declare no competing interests.

Open Access This article is licensed under a Creative Commons Attribution 4.0 International License, which permits use, sharing, adaptation, distribution and reproduction in any medium or format, as long as you give appropriate credit to the original author(s) and the source, provide a link to the Creative Commons licence, and indicate if changes were made. The images or other third party material in this article are included in the article's Creative Commons licence, unless indicated otherwise in a credit line to the material. If material is not included in the article's Creative Commons licence and your intended use is not permitted by statutory regulation or exceeds the permitted use, you will need to obtain permission directly from the copyright holder. To view a copy of this licence, visit http://creativecommons.org/licenses/by/4.0/.

\section{References}

1. Bchetnia M, Girard C, Duchaine C, Laprise C (2020) The outbreak of the novel severe acute respiratory syndrome coronavirus 2 (SARS-CoV-2): A review of the current global status. J Infect Public Health 13:1601-1610. https://doi.org/10.1016/j.jiph.2020. 07.011

2. Guan WJ, Ni ZY, Hu Y, Liang WH, Ou CQ, He JX, Liu L, Shan H, Lei CL, Hui DSC, Du B, Li LJ, Zeng G, Yuen KY, Chen RC, Tang CL, Wang T, Chen PY, Xiang J, Li SY, Wang JL, Liang ZJ, Peng YX, Wei L, Liu Y, Hu YH, Peng P, Wang JM, Liu JY, Chen Z, Li G, Zheng ZJ, Qiu SQ, Luo J, Ye CJ, Zhu SY, Zhong NS, China Medical Treatment Expert Group for C (2020) Clinical Characteristics of Coronavirus Disease 2019 in China. N Engl J Med 382:1708-1720. https://doi.org/10.1056/NEJMoa2002032

3. Wu P, Duan F, Luo C, Liu Q, Qu X, Liang L, Wu K (2020) Characteristics of ocular findings of patients with Coronavirus Disease 2019 (COVID-19) in Hubei Province, China. JAMA Ophthalmol 138:575-578. https://doi.org/10.1001/jamaophthalmol.2020.1291

4. Bressler NM (2020) Ophthalmology and COVID-19. JAMA 324:1143-1144. https://doi.org/10.1001/jama.2020.17595

5. Bertoli F, Veritti D, Danese C, Samassa F, Sarao V, Rassu N, Gambato T, Lanzetta P (2020) Ocular findings in COVID-19 patients: a review of direct manifestations and indirect effects on the eye. J Ophthalmol 2020:4827304. https://doi.org/10.1155/ 2020/4827304

6. KharelSitaula R, Khatri A, Janani MK, Mandage R, Sadhu S, Madhavan HN, Upadhyay MP, Biswas J (2020) Unfolding COVID-19: lessons-in-learning in ophthalmology. Clin Ophthalmol 14:2807-2820. https://doi.org/10.2147/opth.S259857

7. Rokohl AC, Grajewski RS, Matos PAW, Kopecky A, Heindl LM, Cursiefen C (2021) Ocular involvement in COVID-19: conjunctivitis and more. Klin Monbl Augenheilkd 238:555-560. https:// doi.org/10.1055/a-1344-8138
8. Rokohl AC, Grajewski RS, Wawer Matos PA, Koch HL, Dewald F, Klein F, Fätkenheuer G, Lehmann C, Cursiefen C, Heindl LM (2021) No secret hiding place? Absence of SARS-CoV-2 on the ocular surface of 1145 hospitalized patients in a pandemic area. Graefes Arch Clin Exp Ophthalmol 259:1605-1608. https://doi. org/10.1007/s00417-021-05086-3

9. Rokohl AC, Fätkenheuer G, Cursiefen C, Heindl LM (2021) No secret hiding place on the ocular surface: what about after systemic SARS-CoV-2 infection? Graefes Arch Clin Exp Ophthalmol: 1-2 https://doi.org/10.1007/s00417-021-05230-z

10. Marinho PM, Marcos AAA, Branco A, Sakamoto V, Romano A, Schor P, Farah ME, Nascimento H, Belfort R Jr (2020) Results from the SERPICO-19 study - the role of retinal evaluation and in vivo vascular assessment in COVID-19. EClinicalMedicine 29:100655. https://doi.org/10.1016/j.eclinm.2020.100655

11. Ortiz-Seller A, Martínez Costa L, Hernández-Pons A, Valls Pascual E, Solves Alemany A, Albert-Fort M (2020) Ophthalmic and neuro-ophthalmic manifestations of coronavirus disease 2019 (COVID-19). Ocul Immunol Inflamm 28:1285-1289. https://doi. org/10.1080/09273948.2020.1817497

12. Wiersinga WJ, Rhodes A, Cheng AC, Peacock SJ, Prescott HC (2020) Pathophysiology, transmission, diagnosis, and treatment of coronavirus disease 2019 (COVID-19): a review. JAMA 324:782793. https://doi.org/10.1001/jama.2020.12839

13. Hikmet F, Mear L, Edvinsson A, Micke P, Uhlen M, Lindskog C (2020) The protein expression profile of ACE2 in human tissues. Mol Syst Biol 16:e9610. https://doi.org/10.15252/msb.20209610

14. Grajewski RS, Rokohl AC, Becker M, Dewald F, Lehmann C, Fätkenheuer G, Cursiefen C, Klein F, Heindl LM (2021) A missing link between SARS-CoV-2 and the eye?: ACE2 expression on the ocular surface. J Med Virol 93:78-79. https://doi.org/10.1002/ jmv.26136

15. Holappa M, Valjakka J, Vaajanen A (2015) Angiotensin(1-7) and ACE2, "The Hot Spots" of renin-angiotensin system, detected in the human aqueous humor. Open Ophthalmol J 9:28-32. https:// doi.org/10.2174/1874364101509010028

16. Senanayake P, Drazba J, Shadrach K, Milsted A, Rungger-Brandle E, Nishiyama K, Miura S, Karnik S, Sears JE, Hollyfield JG (2007) Angiotensin II and its receptor subtypes in the human retina. Invest Ophthalmol Vis Sci 48:3301-3311. https://doi.org/ 10.1167/iovs.06-1024

17. Lauermann P, Storch M, Weig M, Tampe B, Winkler M, Hoerauf H, Feltgen N, Hakroush S (2020) There is no intraocular affection on a SARS-CoV-2 - Infected ocular surface. Am J Ophthalmol Case Rep 20:100884. https://doi.org/10.1016/j.ajoc.2020.100884

18. Sawant OB, Singh S, Wright RE 3rd, Jones KM, Titus MS, Dennis E, Hicks E, Majmudar PA, Kumar A, Mian SI (2021) Prevalence of SARS-CoV-2 in human post-mortem ocular tissues. Ocul Surf 19:322-329. https://doi.org/10.1016/j.jtos.2020.11.002

19. Casagrande M, Fitzek A, Püschel K, Aleshcheva G, Schultheiss HP, Berneking L, Spitzer MS, Schultheiss M (2020) Detection of SARS-CoV-2 in Human Retinal Biopsies of Deceased COVID-19 Patients. Ocul Immunol Inflamm 28:721-725. https://doi.org/10. 1080/09273948.2020.1770301

20. Bayyoud T, Iftner A, Iftner T, Bartz-Schmidt KU, Rohrbach JM, Ueffing M, Schindler M, Thaler S (2021) Absence of severe acute respiratory syndrome-coronavirus-2 RNA in human corneal tissues. Cornea 40:342-347. https://doi.org/10.1097/ico. 0000000000002479

21. Bayyoud T, Iftner T, Bartz-Schmidt KU, Rohrbach JM, Ueffing M, Schindler M, Thaler S (2021) First results of investigations of SARS-CoV-2 RNA in human corneal tissue. Ophthalmologe 118:78-80. https://doi.org/10.1007/s00347-020-01254-8

22. Kumaran N, Sekhawat V, Mahadeva U, Green A, Douthwaite S, Wong R (2021) Absence of severe acute respiratory syndrome coronavirus 2 in ocular postmortem studies. Can J Ophthalmol 
Journal canadien d'ophtalmologie 56:142-143. https://doi.org/ 10.1016/j.jcjo.2020.10.009

23. List W, Regitnig P, Kashofer K, Gorkiewicz G, Zacharias M, Wedrich A, Posch-Pertl L (2020) Occurrence of SARS-CoV-2 in the intraocular milieu. Exp Eye Res 201:108273. https://doi. org/10.1016/j.exer.2020.108273

24. Koo EH, Eghrari AO, Dzhaber D, Shah A, Fout E, Dubovy S, Maestre-Mesa J, Miller D (2021) Presence of SARS-CoV-2 viral RNA in aqueous humor of asymptomatic individuals. Am J Ophthalmol. https://doi.org/10.1016/j.ajo.2021.05.008

25. Douglas KAA, Douglas VP, Moschos MM (2020) Ocular manifestations of COVID-19 (SARS-CoV-2): a critical review of current literature. In Vivo 34:1619-1628. https://doi.org/10. 21873/invivo.11952

26. Hanley B, Lucas SB, Youd E, Swift B, Osborn M (2020) Autopsy in suspected COVID-19 cases. J Clin Pathol 73:239242. https://doi.org/10.1136/jclinpath-2020-206522

27. Weinberger T, Steffen J, Osterman A, Mueller TT, Muenchhoff M, Wratil PR, Graf A, Krebs S, Quartucci C, Spaeth PM, Grabein B, Adorjan K, Blum H, Keppler OT, Klein M (2021) Prospective longitudinal serosurvey of healthcare workers in the first wave of the severe acute respiratory syndrome coronavirus 2 (SARS-CoV-2) pandemic in a quaternary care hospital in Munich, Germany. Clin Infect Dis. https://doi.org/10.1093/ $\mathrm{cid} / \mathrm{ciaa} 1935$

28. Seah IYJ, Anderson DE, Kang AEZ, Wang L, Rao P, Young BE, Lye DC, Agrawal R (2020) Assessing viral shedding and infectivity of tears in coronavirus disease 2019 (COVID-19) patients. Ophthalmology 127:977-979. https://doi.org/10.1016/j.ophtha. 2020.03.026

29. Seah I, Agrawal R (2020) Can the coronavirus disease 2019 (COVID-19) affect the eyes? A review of coronaviruses and ocular implications in humans and animals. Ocul Immunol Inflamm 28:391-395. https://doi.org/10.1080/09273948.2020.1738501

30. Chen L, Liu M, Zhang Z, Qiao K, Huang T, Chen M, Xin N, Huang Z, Liu L, Zhang G, Wang J (2020) Ocular manifestations of a hospitalised patient with confirmed 2019 novel coronavirus disease. Br J Ophthalmol 104:748-751. https://doi.org/10.1136/ bjophthalmol-2020-316304

31. Pardhan S, Vaughan M, Zhang J, Smith L, Chichger H (2020) Sore eyes as the most significant ocular symptom experienced by people with COVID-19: a comparison between pre-COVID-19 and during COVID-19 states. BMJ Open Ophthalmol 5:e000632. https://doi.org/10.1136/bmjophth-2020-000632

32. Marinho PM, Marcos AAA, Romano AC, Nascimento H, Belfort R Jr (2020) Retinal findings in patients with COVID-19. Lancet 395:1610. https://doi.org/10.1016/s0140-6736(20)31014-x

33. Landecho MF, Yuste JR, Gándara E, Sunsundegui P, Quiroga J, Alcaide AB, García-Layana A (2021) COVID-19 retinal microangiopathy as an in vivo biomarker of systemic vascular disease? J Intern Med 289:116-120. https://doi.org/10.1111/joim.13156

34. Pereira LA, Soares LCM, Nascimento PA, Cirillo LRN, Sakuma HT, Veiga GLD, Fonseca FLA, Lima VL, Abucham-Neto JZ (2020) Retinal findings in hospitalised patients with severe COVID-19. Br J Ophthalmol. https://doi.org/10.1136/bjophthalm ol-2020-317576

35. Abrishami M, Emamverdian Z, Shoeibi N, Omidtabrizi A, Daneshvar R, SaeidiRezvani T, Saeedian N, Eslami S, Mazloumi M, Sadda S, Sarraf D (2021) Optical coherence tomography angiography analysis of the retina in patients recovered from COVID19: a case-control study. Can J Ophthalmol 56:24-30. https://doi. org/10.1016/j.jcjo.2020.11.006

36. Pirraglia MP, Ceccarelli G, Cerini A, Visioli G, d'Ettorre G, Mastroianni CM, Pugliese F, Lambiase A, Gharbiya M (2020) Retinal involvement and ocular findings in COVID-19 pneumonia patients. Sci Rep 10:17419. https://doi.org/10.1038/ s41598-020-74446-6

37. Letko M, Marzi A, Munster V (2020) Functional assessment of cell entry and receptor usage for SARS-CoV-2 and other lineage B betacoronaviruses. Nat Microbiol 5:562-569. https://doi.org/ 10.1038/s41564-020-0688-y

38. Wang P, Lau SY, Deng S, Chen P, Mok BW, Zhang AJ, Lee AC, Chan KH, Tam RC, Xu H, Zhou R, Song W, Liu L, To KK, Chan JF, Chen Z, Yuen KY, Chen H (2021) Characterization of an attenuated SARS-CoV-2 variant with a deletion at the S1/S2 junction of the spike protein. Nat Commun 12:2790. https://doi. org/10.1038/s41467-021-23166-0

Publisher's note Springer Nature remains neutral with regard to jurisdictional claims in published maps and institutional affiliations. 